\title{
Fatty acid profile, chemical composition, and sensory effects of crude glycerin on the longissimus dorsi of crossbred Boer goat kids
}

\section{Karlyene Sousa da Rocha ${ }^{1}$, Henrique Nunes Parente ${ }^{2}$, Michelle de Oliveira Maia Parente ${ }^{2}$, Evandro Maia Ferreira ${ }^{3}$, Jocélio dos Santos Araújo², Rita de Cássia Ramos do Egypto Queiroga $^{4}$, Marta Suely Madruga ${ }^{5}$, Ana Sancha Malveira Batista ${ }^{6}$}

\author{
${ }^{1}$ Universidade Federal do Maranhão, Programa de Pós-graduação em Ciência Animal, Chapadinha, MA, Brasil. \\ ${ }^{2}$ Universidade Federal do Maranhão, Centro de Ciências Agrárias e Ambientais, Chapadinha, MA, Brasil. \\ ${ }^{3}$ Universidade Estadual de Ponta Grossa, Departamento de Zootecnia, Ponta Grossa, PR. Brasil. \\ ${ }^{4}$ Universidade Federal da Paraíba, Departamento de Nutrição, João Pessoa, PB, Brasil. \\ ${ }^{5}$ Universidade Federal da Paraíba, Departamento de Tecnologia Química e Alimentos, João Pessoa, PB, Brasil. \\ ${ }^{6}$ Universidade Estadual Vale do Acaraú, Departamento de Zotoecnia, Sobral, CE, Brasil.
}

\begin{abstract}
The objectives of this trial were to evaluate the fatty acid profile, chemical composition, and sensory effects of crude glycerin on the longissimus dorsi muscle of crossbred Boer goat kids. Twenty crossbred Boer goat kids (20.8 $\pm 2.9 \mathrm{~kg}$ of BW at slaughter) were used in a completely randomized block design to determine the effect of partial replacement of corn by crude glycerin on chemical composition, longissimus dorsi muscle fatty acid profile, and sensory characteristics of meat. Kids were penned individually for $51 \mathrm{~d}$ and fed an isonitrogenous ( $140.0 \pm 2.0 \mathrm{~g} \cdot \mathrm{kg}^{-1} \mathrm{CP}$, DM basis) diet composed of $700 \mathrm{~g} \cdot \mathrm{kg}^{-1}$ concentrate and 300 g. $\mathrm{kg}^{-1}$ Tifton (Cynodon sp.) hay. Increasing levels of crude glycerin ( $80.0 \mathrm{~g} / 100 \mathrm{~g}$ glycerol, DM basis) were $0,40,80$ or 120 g. $\mathrm{kg}^{-1}$. There was no effect on the moisture, protein, or total lipids in the longissimus dorsi; however, the ash content decreased linearly with glycerin addition. Linear decrease for linoleic acid (3.57, 2.84, 3.76, and 2.33) and $\omega 6: \omega 3$ ratio (10.61, 9.71, 7.26, and 7.18 for CG0, CG40, CG80 and CG120, respectively) was observed with crude glycerin inclusion. Saturated, monounsaturated, and polyunsaturated fatty acids were not affected by treatments. In the sensory assessment, crude glycerin changed the toughness, color intensity, and overall appreciation of the longissimus dorsi muscle. The partial replacement of corn by crude glycerin has a low impact on chemical composition and meat fatty acid profile. Based on the overall appreciation, it is recommended to include $80 \mathrm{~g} \cdot \mathrm{kg}^{-1}$ crude glycerin in the diet.
\end{abstract}

Key Words: glycerol, meat flavor, meat quality

\section{Introduction}

The increase in biodiesel production has led to increased stocks of glycerol with a subsequent price reduction, making glycerol a potential high-energy feed source for ruminants (Avila et al., 2011). Crude glycerin is a co-product of biodiesel production with a high concentration of glycerol. Due to the high production of biodiesel, there is a wide availability of crude glycerin, and it is becoming an interesting ingredient for animal nutrition.

A potential application for glycerin is as a gluconeogenic substrate for ruminants (Chung et al., 2007). Glycerol can be converted to glucose in the liver and can provide energy for cellular metabolism (Goff and Horst, 2001). Glycerol enters the gluconeogenic pathway at the level of

Received September 8, 2014 and accepted April 7, 2015

Corresponding author: michellemrn@ig.com.br

http://dx.doi.org/10.1590/S1806-92902015000700005

Copyright $@ 2015$ Sociedade Brasileira de Zootecnia. This is an Open Access article distributed under the terms of the Creative Commons Attribution Non-Commercial License, which permits unrestricted non-commercial use, distribution, and reproduction in any medium, provided the original work is properly cited. dihydroxyacetone phosphate and 3-phosphoglyceraldehyde (Leng, 1970; Krehbiel, 2008). Therefore, glycerin could be used as an energetic ingredient in animal diets replacing cereals, which are usually more expensive.

Several researchers (Eiras et al., 2014; Lage et al., 2014) have estimated the energy value of crude glycerin in beef and lamb diets. However, to our knowledge, there are no studies that evaluate the effects on the meat quality of glycerin supplementation to finishing goat kids fed highconcentrate diets.

The objective of this study were to determine the effects of the partial replacement of corn by crude glycerin on the chemical composition, sensorial characteristics, and fatty acid profile of the longissimus dorsi muscle in goat kids.

\section{Material and Methods}

The experiment was conducted in Northeast Brazil (034' $33^{\prime \prime}$ S, 4321'21" W). Experimental protocols were approved by the Institutional Animal Care and Use Committee of Universidade Federal do Maranhão (Case no. $23115.003553 / 2012-74)$. 
Twenty male castrated crossbred Boer goat kids, with an initial body weight (BW) of $16.1 \pm 2.1 \mathrm{~kg}$, at $90 \pm 18$ days of age, were used in this study. The animals were housed in covered pens ( 1 animal/pen) with concrete floor and dimensions of $1.3 \mathrm{~m} \times 3.5 \mathrm{~m}$. All animals were dewormed with $1 \mathrm{~g} / \mathrm{kg}$ moxidectin (Cydectin, Fort Dodge Animal Health, Campinas, SP, Brazil) at a dose of $1 \mathrm{~mL} / 50 \mathrm{~kg}$ of BW.

Initially, kids were subjected to a period of 14 days of adaptation to the experimental diets. After this, animals were divided in a randomized complete block design with five blocks and four experimental treatments. The treatments were defined by four concentrations of crude glycerin $(0$, 40,80 , and $120 \mathrm{~g} / \mathrm{kg}$ in the dietary DM) as a substitute of ground corn (Table 1). Experimental diets were composed of $300 \mathrm{~g} . \mathrm{kg}^{-1}$ of Tifton 85 (Cynodon sp.) hay and $700 \mathrm{~g} \cdot \mathrm{kg}^{-1}$ of concentrate (DM basis). Diets were isonitrogenous (140 g. $\mathrm{kg}^{-1} \mathrm{CP}$, DM basis) and were formulated according to the National Research Council for a gain of 150 g.day ${ }^{-1}$ (NRC, 2007).

The crude glycerin used in this study originated from vegetable oils of castor bean, soybean, cottonseed, and sunflower and had $0.07 \mathrm{~g} / 100 \mathrm{~g}$ of methanol and 80.0 $\mathrm{g} / 100 \mathrm{~g}$ of glycerol. It was produced by methylic route and obtained from Petrobrás Biocombustíveis S.A, QuixadáCE, Brazil.

Kids were fed once a day at $08.00 \mathrm{~h}$. The amount of feed offered to animals were calculated according to the previous dry matter intake (DMI) and adjustments were made whenever necessary for the refused feed not to exceed 100 g. $\mathrm{kg}^{-1}$ of daily intake.

At the end of the 51 days of the feeding trial, the animals (20.8 $\pm 2.9 \mathrm{~kg} \mathrm{BW})$ were subjected to solid fasting

Table 1 - Ingredients and chemical composition of experimental diets (g. $\mathrm{kg}^{-1}, \mathrm{DM}$ basis)

\begin{tabular}{|c|c|c|c|c|}
\hline \multirow[b]{2}{*}{ Ingredient } & \multicolumn{4}{|c|}{$\operatorname{Diet}^{1}$} \\
\hline & CG0 & CG40 & CG80 & CG120 \\
\hline Tifton hay & 300.0 & 300.0 & 300.0 & 300.0 \\
\hline Ground corn & 530.0 & 470.0 & 420.0 & 378.0 \\
\hline Soybean meal & 143.0 & 163.0 & 173.0 & 175.0 \\
\hline Crude glycerin & 0.0 & 40.0 & 80.0 & 120.0 \\
\hline Limestone & 12.0 & 12.0 & 12.0 & 12.0 \\
\hline Mineral premix ${ }^{2}$ & 15.0 & 15.0 & 15.0 & 15.0 \\
\hline \multicolumn{5}{|l|}{ Chemical analysis } \\
\hline Dry matter, as-fed basis & 856.4 & 856.3 & 857.2 & 858.1 \\
\hline Crude protein & 136.0 & 140.9 & 140.9 & 139.3 \\
\hline Neutral detergent fiber & 323.4 & 319.8 & 315.7 & 311.4 \\
\hline
\end{tabular}

and free water for $16 \mathrm{~h}$ and slaughtered in accordance with the RIISPOA standards (Brasil, 1997).

The longisimus dorsi muscle was separated from the bone for quantitative assessments of chemical composition, lipid profile, and sensory characteristics. They were packed in plastic bags, and finally frozen in commercial freezers at $-18{ }^{\circ} \mathrm{C}$ for a period not exceeding two months, when the analyses were performed. All goat meat evaluations were performed in triplicate.

Longissimus dorsi muscle samples were thawed in a refrigerator for $24 \mathrm{~h}$. Then, they were cleaned and ground in a blender until obtaining a homogeneous sample. The moisture content was determined by drying the meat in an oven at $105{ }^{\circ} \mathrm{C}$ until constant weight (Method 985.41; AOAC, 2000); the ash content was obtained by burning the material in muffle at $550{ }^{\circ} \mathrm{C}$ (Method 920.15; AOAC, 2000); and the nitrogen content was determined through the Kjeldahl method, using the factor of 6.38 to convert the total nitrogen into protein nitrogen (Method 928.08; AOAC, 2000). The total lipid concentrations were measured in accordance with the method of Folch et al. (1957), by subjecting the sample to extraction with a mixture of chloroform and methanol (2:1 ratio).

After extraction of total lipids, fatty acid methyl esters were prepared by direct esterificationof lipids in muscle tissue, according to Hartman and Lago (1973). The resulting fatty acid methyl esthers (FAME) were then analyzed by GLC using a VARIAN 430-GC (California, USA) equipped with a flame ionization detector. The separation occurred in a fused silica capillary column (CP WAX 52 CB, VARIAN), polar type, packed with Polyethylene, with dimensions of $60 \mathrm{~m} \times 0.25 \mathrm{~mm}$ id $\times 0.2 \mu$ of film thickness. Methyl esters samples $(2 \mu \mathrm{L})$ were injected into a split/splitless type injector at $250^{\circ} \mathrm{C}$. The chromatograms, with retention times and the percentages of areas of fatty acids, were recorded using the Galaxie Chromatography Data System software. Helium was used as the carrier gas $(1 \mathrm{~mL} / \mathrm{min})$. The initial oven temperature was $100{ }^{\circ} \mathrm{C}$, set to reach $240{ }^{\circ} \mathrm{C}$, adding $2.5^{\circ} \mathrm{C}$ per minute, standing for 20 $\mathrm{min}$. The injector and detector temperatures were maintained at $250{ }^{\circ} \mathrm{C}$ and $260{ }^{\circ} \mathrm{C}$, respectively. The fatty acids were identified by comparing retention times of the methyl esters of the standards samples (SupelcoME19-Kit - Fatty Acid Methyl Esters C6-C22).

The auxiliary gases were nitrogen $(30 \mathrm{~mL} / \mathrm{min})$, hydrogen $(30 \mathrm{~mL} / \mathrm{min})$, and synthetic air $(300 \mathrm{~mL} / \mathrm{min})$. The fatty acids were identified by comparing the retention times of methyl esters of the samples with authentic standards (Merck, USA). The fatty acids results were expressed in $\mathrm{g} / 100 \mathrm{~g}$. 
The day before sensory assessment, samples were thawed initially at room temperature $(6 \mathrm{~h})$ and then kept at $4{ }^{\circ} \mathrm{C}$ overnight. In the morning of sensory assessment, the longissimus dorsi muscle sample was cut into $2.0 \mathrm{~cm}$-thick steaks and a section from the lateral edge of the steak (the "tail"), consisting mainly of fat with a small amount of muscle, was also removed.

Chops were placed on a domestic grill (Tricity Double Oven and Grill, Model 2142, Thorn Domestic Appliances, England, UK) and cooked, turning every $3 \mathrm{~min}$, to an internal muscle temperature of $75{ }^{\circ} \mathrm{C}$ as measured by a thermocouple probe (Comark, Model 9001, fitted with a K-type thermocouple, Stevenage, Hertfordshire SG12TA, UK) inserted into the approximate geometric center of each steak.

Ten trained taste panel members assessed lamb juiciness intensity, toughness, color intensity, aroma, flavor, and overall appreciation using a non-structured line scale measuring $9 \mathrm{~cm}$. More details are in Sanudo et al. (1998).

Unsalted crackers and water at room temperature were used to dissipate residual flavors and particles among evaluations.

Data were analyzed as a completely randomized block using the SAS (Statistical Analysis System, version 9.0) software. The blocks were defined according to the initial BW of the kids. A check of homoscedasticity of variance was performed using Levene's test. The MIXED procedure was used to analyze the effects of treatment on meat quality traits, with the animal serving as the experimental unit according to the following statistical model: $\mathrm{Y}=\mu+\mathrm{Bi}+\mathrm{Dj}+\mathrm{Eij}$, in which: $\mu$ overall mean; $\mathrm{Bi}=$ effect of block; $\mathrm{Dj}=$ effect of diet; and Eij = the residual error. Means were obtained using the LSMEANS command. The blocks and animals were included as random effects, while diet was included as fixed effect.

Orthogonal polynomials for treatment responses were determined by linear and quadratic responses to increasing concentrations of crude glycerin incorporation. Effects were declared significant at $\mathrm{P}<0.05$ and trends were discussed between $\mathrm{P}>0.05$ and $\mathrm{P}<0.10$. For the sensory analysis, means were compared using the Ryan-Einot-GabrielWelsch test $(\mathrm{P}<0.05)$.

\section{Results}

The addition of crude glycerin did not change the moisture, protein, or total lipid concentrations of the meat (Table 2). However, the ash content $(\mathrm{g} / 100 \mathrm{~g})$ decreased linearly $(\mathrm{P}<0.01)$ with the increase of crude glycerin concentration in the diets.

There was no effect of crude glycerin on the total concentrations of saturated (SFA), monounsaturated (MUFA), and polyunsaturated (PUFA) fatty acids of the meat (Table 3). Additionally, meat monounsaturated: saturated fatty acid (M:S) and polyunsaturated:saturated fatty acid $(\mathrm{P}: \mathrm{S})$ ratios and the $(\mathrm{C} 18: 0+\mathrm{C} 18: 1) / \mathrm{C} 16: 0$ ratio were not affected by the experimental diets (Table 3 ). However, the linoleic concentrations and the $\omega 6: \omega 3$ ratio in the meat decreased linearly $(\mathrm{P}<0.05)$ with the inclusion of crude glycerin.

There were no significant differences in juiciness, flavor, and aroma among treatments, with the average values within the range of 4.59 to 5.44 for juiciness, 4.16 to 4.62 for flavor, and 4.19 to 4.85 for aroma (Table 4). However, diet affected toughness, color, and overall appreciation of the meat $(\mathrm{P}<0.05)$.

The toughness was lower when kids were fed 40 g. $\mathrm{kg}^{-1}$ of crude glycerin in the diet in comparison with $80 \mathrm{~g} \cdot \mathrm{kg}^{-1}$ and 120 g. $\mathrm{kg}^{-1}$ of crude glycerin. However, the value did not differ from the control diet.

The color was less expressive $(\mathrm{P}<0.05)$ when animals were fed diets with 80 g. $\mathrm{kg}^{-1}$ of crude glycerin. The meat of kids fed the control diet and $40 \mathrm{~g} \cdot \mathrm{kg}^{-1}$ of crude glycerin showed higher $(\mathrm{P}<0.05)$ overall appreciation when compared with those fed 120 g. kg ${ }^{-1}$ of crude glycerin. However, the appreciation values did not differ ( $P>0.05$ ) from the meat of kids fed $80 \mathrm{~g} \cdot \mathrm{kg}^{-1}$ of crude glycerin.

Table 2 - Chemical composition of the longissimus dorsi from crossbred Boer goat kids fed glycerin

\begin{tabular}{|c|c|c|c|c|c|c|c|}
\hline \multirow[b]{2}{*}{ Item $(\mathrm{g} / 100 \mathrm{~g})$} & \multicolumn{4}{|c|}{$\operatorname{Diet}^{1}$} & \multirow[b]{2}{*}{ SEM } & \multicolumn{2}{|c|}{ Effect $^{2}$} \\
\hline & CG0 & CG40 & CG80 & CG120 & & $\mathrm{L}$ & Q \\
\hline Moisture & 72.73 & 72.00 & 73.15 & 72.69 & 0.41 & 0.590 & 0.747 \\
\hline Total lipids & 3.43 & 3.83 & 3.06 & 3.71 & 0.42 & 0.973 & 0.778 \\
\hline Ash & 1.14 & 1.09 & 1.11 & 1.06 & 0.01 & 0.004 & 0.938 \\
\hline
\end{tabular}

SEM - standard error of the mean.

${ }^{1}$ CG0 - 0 g.kg ${ }^{-1}$, no crude glycerin; CG40 - 40 g.kg-1 crude glycerin; CG80 - 80 g.kg-1 crude glycerin; CG120 - 120 g.kg-1 crude glycerin.

${ }^{2}$ Linear (L) and quadratic (Q) effects. 
Table 3 - Fatty acid profile of the longissimus dorsi muscle from crossbred Boer goat kids fed crude glycerin

\begin{tabular}{|c|c|c|c|c|c|c|c|}
\hline \multirow[b]{2}{*}{ Item } & \multicolumn{4}{|c|}{$\operatorname{Diet}^{1}$} & \multirow[b]{2}{*}{ SEM } & \multicolumn{2}{|c|}{ Effect $^{2}$} \\
\hline & CG0 & CG40 & CG80 & CG120 & & $\mathrm{L}$ & Q \\
\hline Saturated & 42.69 & 42.47 & 41.35 & 42.97 & 1.61 & 0.952 & 0.386 \\
\hline C10:0 (Capric) & 0.13 & 0.09 & 0.09 & 0.07 & 0.01 & 0.066 & 0.668 \\
\hline C12:0 (Lauric) & 0.09 & 0.08 & 0.06 & 0.05 & 0.01 & 0.222 & 0.878 \\
\hline C14:0 (Miristic) & 1.44 & 1.51 & 1.68 & 1.55 & 0.10 & 0.308 & 0.391 \\
\hline C16:0 (Palmitic) & 20.45 & 20.72 & 20.18 & 20.55 & 0.52 & 0.923 & 0.921 \\
\hline C18:0 (Estearic) & 16.14 & 15.88 & 14.69 & 16.46 & 1.19 & 0.963 & 0.357 \\
\hline Monounsaturated & 52.42 & 53.45 & 53.07 & 53.37 & 1.96 & 0.578 & 0.697 \\
\hline C16:1 (Palmitoleic) & 1.70 & 1.76 & 1.73 & 1.98 & 0.18 & 0.285 & 0.569 \\
\hline C18:1 $\omega-9$ (Oleic) & 48.00 & 48.68 & 47.59 & 47.84 & 1.66 & 0.670 & 0.793 \\
\hline C18:1 $\omega-9$ trans (Elaidic) & 2.02 & 1.73 & 1.93 & 1.80 & 0.12 & 0.404 & 0.507 \\
\hline C20:1 $\omega-9$ cis (Eicosanoic) & 0.11 & 0.11 & 0.12 & 0.13 & 0.01 & 0.054 & 0.386 \\
\hline Polyunsaturated & 4.83 & 4.02 & 5.60 & 3.76 & 0.58 & 0.284 & 0.156 \\
\hline C18:2 $\omega-6$ (Linoleic) & 3.57 & 2.84 & 3.76 & 2.33 & 0.35 & 0.017 & 0.093 \\
\hline C20:2 $\omega-6$ (Eicosadienoic) & 0.60 & 0.59 & 0.81 & 0.60 & 0.10 & 0.669 & 0.322 \\
\hline C20:3 $\omega-6$ (dihomo - $\gamma$ - linolenic) & 0.20 & 0.19 & 0.26 & 0.20 & 0.02 & 0.222 & 0.095 \\
\hline C20:5 $\omega 3$ (EPA) & 0.40 & 0.40 & 0.58 & 0.40 & 0.06 & 0.437 & 0.265 \\
\hline Others & 4.54 & 4.85 & 6.18 & 6.34 & 0.58 & 0.034 & 0.901 \\
\hline $\mathrm{M}: \mathrm{S}$ & 1.24 & 1.27 & 1.30 & 1.27 & 0.09 & 0.837 & 0.470 \\
\hline$P: S$ & 0.12 & 0.10 & 0.13 & 0.09 & 0.01 & 0.494 & 0.565 \\
\hline$\omega 6: \omega 3$ & 10.61 & 9.71 & 7.26 & 7.18 & 1.13 & 0.027 & 0.680 \\
\hline$(\mathrm{C} 18: 0+\mathrm{C} 18: 1) / \mathrm{C} 16: 0$ & 3.16 & 3.14 & 3.10 & 3.08 & 0.11 & 0.591 & 0.988 \\
\hline
\end{tabular}

SEM - standard error of the mean.

$\mathrm{M}: \mathrm{S}$ - ratio between monounsaturated and saturated fatty acids; P:S - ratio between polyunsaturated and saturated fatty acids; $\omega 6: \omega 3$ - ratio between $\omega 6$ and $\omega 3$ fatty acids.

${ }^{1}$ CG0 - 0 g.kg ${ }^{-1}$, no crude glycerin; CG40 - 40 g.kg-1 crude glycerin; CG80 - 80 g.kg-1 crude glycerin; CG120 - 120 g.kg ${ }^{-1}$ crude glycerin.

${ }^{2}$ Linear (L) and quadratic (Q) effects.

Table 4 - Sensory assessment of the longissimus dorsi from crossbred Boer goat kids fed crude glycerin

\begin{tabular}{|c|c|c|c|c|c|}
\hline \multirow[b]{2}{*}{ Item (points) } & \multicolumn{4}{|c|}{$\operatorname{Diet}^{1}$} & \multirow[b]{2}{*}{ SEM } \\
\hline & CG0 & CG40 & CG80 & CG120 & \\
\hline Toughness & $4.55 \mathrm{ab}$ & $3.56 \mathrm{a}$ & $4.75 b$ & $4.76 \mathrm{~b}$ & 0.25 \\
\hline Flavor & 4.48 & 4.62 & 4.52 & 4.16 & 0.25 \\
\hline Color & $5.24 \mathrm{a}$ & $5.62 \mathrm{a}$ & $4.35 \mathrm{~b}$ & $5.20 \mathrm{a}$ & 0.23 \\
\hline Aroma & 4.58 & 4.85 & 4.42 & 4.19 & 0.29 \\
\hline Overall appreciation & $7.10 \mathrm{a}$ & $6.86 \mathrm{a}$ & $6.44 \mathrm{ab}$ & $5.94 \mathrm{~b}$ & 0.19 \\
\hline
\end{tabular}

Means in the same row followed by different letters differ.

SEM - standard error of the mean.

${ }^{1}$ CG0 - 0 g.kg ${ }^{-1}$, no crude glycerin; CG40 - 40 g.kg-1 crude glycerin; CG80 - 80 g. $\mathrm{kg}^{-1}$ crude glycerin; CG120 - 120 g.kg ${ }^{-1}$ crude glycerin.

\section{Discussion}

In the present study, it was expected that the inclusion of crude glycerin in the diets would increase the intramuscular fat content because, according to Schoonmaker et al. (2004), the crude glycerin likely would decrease the acetate: propionate ratio in the rumen, possibly due to the increases in propionate, the precursor of glucose, which is the main carbon source for the deposition of fat tissue.

According to Smith and Crouse (1994), in research conducted with Angus cattle, the glucose that originated from the propionic acid is responsible for up to $10 \mathrm{~g} \cdot \mathrm{kg}^{-1}$ of the acetyl units in the subcutaneous fat tissue, and 500 to $750 \mathrm{~g} \cdot \mathrm{kg}^{-1}$ of the intramuscular fat tissue. However, the absence of an improvement in intramuscular fat accretion in his study seemingly refutes this hypothesis because the feeding of crude glycerin may result in the suppression of intramuscular fat accretion (Drouillard, 2012) or may tend to decrease the deposition of intramuscular fat within the longissimus dorsi muscle (Elam et al., 2008).

The ash content decreased linearly with crude glycerin supplementation. There was no biological explanation for this result because the ash content is usually affected by the age of the animal (Madruga et al., 1999) and not by diet effects. In this study, kids were slaughtered at similar ages ( $150 \pm 18$ days old). The ash values of the meat were close to those found by Lage et al. (2014) in research with lambs fed diets composed of $300 \mathrm{~g} \cdot \mathrm{kg}^{-1}$ of corn silage and 700 g. $\mathrm{kg}^{-1}$ concentrate (DM basis).

There was no effect of crude glycerin on the total concentrations of saturated, monounsaturated, and polyunsaturated fatty acids in the meat (Table 3). The main 
fatty acids found in the longissimus dorsi muscle were C18:1 $\omega-9$ cis (oleic), C16:0 (palmitic), C18:0 (stearic), and C18: $2 \omega-6$ (linoleic) (Table 3). This is in agreement with the view by Banskalieva et al. (2000) who, after assessments in several studies, found same fatty acids as the main muscle lipids in goats.

Saturated and monounsaturated fatty acids represented approximately $42.4 \mathrm{~g} / 100 \mathrm{~g}$ and $53.1 \mathrm{~g} / 100 \mathrm{~g}$ of total fatty acids (FA) in the longissimus muscle (Table 3), respectively. Krueger et al. (2010) reported that glycerol has the potential to increase the amount of unsaturated fatty acids available to be incorporated in meat products, due to the inhibition of lipolysis in the rumen. However, in this study, the total concentrations of polyunsaturated fatty acids in the meat did not change with crude glycerin inclusion.

Linoleic acid $(\mathrm{C} 18: 2)$ decreased $(\mathrm{P}<0.05)$ with an increase in the crude glycerin levels. The lower content of this FA in the longissimus muscle of goat kids might be related to the replacement of corn by glycerin because the concentration of linoleic acid is higher in corn.

The PUFA:SFA ratio was not affected by the addition of crude glycerin and the values varied from $0.09\left(0 \mathrm{~g} \cdot \mathrm{kg}^{-1}\right.$ of crude glycerin) to 0.12 (120 g. $\mathrm{kg}^{-1}$ of crude glycerin). This ratio is below the recommended rate of 0.40 , the minimum value that is considered beneficial to human health.

The $\omega 6: \omega 3$ ratio had an average of 8.7 , which is not considered healthy and is above the rate of 4 recommended by Wood et al. (2003). This high ratio may be explained by the higher proportion of concentrate in the diets, which increases the total $\omega 6$ fatty acids in the diets.

The crude glycerin decreased linearly $(\mathrm{P}<0.05)$ the $\omega 6: \omega 3$ ratio (10.61 to $7.18 \mathrm{~g} / 100 \mathrm{~g})$, due to the addition of glycerin in replacement by corn, which is rich in linoleic fatty acid $(\omega 6)$.

Considering that oleic fatty acid (C18:1) decreases the plasma cholesterol level in the blood, while palmitic fatty acid (C16:0) raises the level and stearic acid (C18:0) has no influence (Rhee et al., 2000), it is important to analyze the behavior of these three fatty acids. Therefore, the (C18:0+C18:1)/C16:0 ratio could possibly better describe the effects of different fatty acids on human health. The mean value found in this study for this ratio was 3.12, which is above the values found in the review carried out by Banskalieva et al. (2000), which are between 2 and 3 for goat meat.

The results for juiciness (5.06 points) were considered very good (Lepetit, 2008) (Table 4). Juiciness is related to moisture and intramuscular contents present in the cooked meat. Because the chemical composition of the meat, except the ash content, was not altered by the increases of crude glycerin concentration, there was also an absence of effect for juiciness.

Aroma is also an important attribute when purchasing a product. According to Madruga (1997), the aroma and taste of the meat are directly associated with the fat content in the muscle. In the present study, the treatments produced no changes in these qualities, which demonstrated that crude glycerin did not change the properties that alter the flavor and aroma on the meat of goat kids. Similar sensory attributes were found by Eiras et al. (2014), who evaluated the meat of cattle fed diets with up to 180 g. $\mathrm{kg}^{-1}$ crude glycerin.

According to Mancini and Hunt (2005), meat color is an important commercial trait that influences consumer behavior. Although the treatment with $80 \mathrm{~g} \mathrm{~kg}^{-1}$ of crude glycerin produced a less expressive color (4.35) (Table 4), this value was considered satisfactory (Mancini and Hunt, 2005). This outcome confirmed that the substitution did not alter the color attribute of goat meat or cause rejection by the tasters and that the acceptance of color depends on several factors, among them regional consumption habits and customs (Pinheiro et al., 2010).

As previously mentioned, juiciness and flavor can influence the results for overall appreciation (Hocquette et al., 2012). However, consumers did not detect differences in these characteristics in the meat. Indeed, meat appreciation may be altered by toughness (Wood et al., 2008).

\section{Conclusions}

The inclusion of crude glycerin does not affect the chemical composition, except of ash, of the meat of goat kids and promotes improvement in the $\omega 6: \omega 3$ ratio. Based on its overall appreciation, it is recommended to include 80 g. $\mathrm{kg}^{-1}$ crude glycerin in the diet.

\section{Acknowledgments}

The authors acknowledge FAPEMA (Fundação de Amparo à Pesquisa e ao Desenvolvimento Científico e Tecnológico do Maranhão) for the financial support.

\section{References}

AOAC - Association of Official Analytical Chemistry. 2000. Official methods of analysis. AOAC International, Washington, USA.

Avila, J. S.; Chaves, A. V.; Hernandez-Calva, L. M.; Beauchemin, K. A.; McGinn, S. M.; Wang, Y.; Harstad, O. M. and McAllister, T. A. 2011. Effects of replacing barley grain in feedlot diets with increasing levels of glycerol on in vitro fermentation and methane production. Animal Feed Science Technology $166: 265-268$ 
Banskalieva, V.; Sahlu, T. and Goetsch, A. L. 2000. Fatty acid composition of goat muscles and fat depots: a review. Small Ruminant Research 37:255-268.

Brasil. Ministério da Agricultura, Pecuária e Abastecimento. 1997. Regulamento da inspeção industrial e sanitária de produtos de origem animal. Ministério da Agricultura, Pecuária e Abastecimento, Brasília.

Chung, Y. H.; Rico, D. E.; Martinez, C. M.; Cassidy, T. W.; Noirot, V.; Ames, A. and Varga, G. A. 2007. Effects of feeding dry glycerin to early postpartum Holstein dairy cows on lactational performance and metabolic profiles. Journal Dairy Science 90:5682-5691.

Drouillard, J. S. 2012. Utilization of crude glycerin in beef cattle. p.155-161. In: Biofuel co-products as livestock feed - Opportunities and challenges. Makkar, H. P. S., ed. Food and Agriculture Organization of the United Nation, Rome.

Eiras, C. E.; Marques, J. A.; Prado, R. M.; Valero, M. V.; Bonafé, E. G.; Zawadzki, F.; Perotto, D. and Prado, I. N. 2014. Glycerin levels in the diets of crossbred bulls finished in feedlot: Carcass characteristics and meat quality. Meat Science 96:930-936.

Elam, N. A.; Eng, K. S.; Bechtel, B.; Harris, J. M. and Crocker, R. 2008. Glycerol from biodiesel production: Considerations for feedlot steers. In: Proceedings of the Southwest Nutrition Conference. Tempe, AZ, USA.

Folch, J.; Less, M. and Stanley, S. 1957. A simple method for the isolation andpurification of total lipids from animal tissues. Journal of Biology Chemistry 226:497-509.

Goff, J. P. and Horst, R. L. 2001. Oral glycerol as an aid in treatment of ketosis/fatty liver complex. Journal Dairy Science 84(Suppl. 1):153 (Abstr.).

Hartman, L. and Lago, R. C. A. 1973. Rapid preparation of fatty acids methyl esters. Laboratory Practice 22:475-476.

Hocquette, J. F.; Botreau, R.; Picard, B.; Jacquet, A.; Pethick, D. W. and Scollan, N. D. 2012. Opportunities for predicting and manipulating beef quality. Meat Science 92:197-209.

Krehbiel, C. R. 2008. Ruminal and physiological metabolism of glycerin. Journal of Animal Science 86(E-Suppl. 2):392 (Abstr.).

Krueger, N. A.; Anderson, R. C.; Tedeschi, L. O.; Callaway, T. R.; Edrington, T. S. and Nisbet, D. J. 2010. Avaliação da alimentação de glicerol na produção de ácido livre de gordura e de fermentação cinética de micróbios ruminal in vitro. Bioresource Tecnology 101:8469-8472.

Lage, J. F.; Paulino, P. V. R.; Pereira, L. G. R.; Duarte, M. S.; Valadares Filho, S. C.; Oliveira, A. S.; Souza, N. K. P. and Lima J. C. M. 2014. Carcass characteristics of feedlot lambs fed crude glycerin contaminated with high concentrations of crude fat. Meat Science 96:108-113.

Leng, R. A. 1970. Glucose synthesis in ruminants. p.241-242. In: Advances in veterinary science and comparative medicine. v.14. Brandly, C. A. and Cornelius, C. E., eds. Academic Press, New York, NY.

Lepetit, J. 2008. Collagen contribution to meat toughness: Theoretical aspects. Meat Science 80:960-967.

Madruga, M. S. 1997. Revisão: formação do aroma cárneo. Boletim da Sociedade Brasileira de Ciência e Tecnologia de Alimentos 1:33-41.

Madruga, M. S.; Arruda, S. G. B.; Araújo, E. M.; Andrade, L. T.; Nascimento, J. C. and Costa, R. G. 1999. Efeito da idade de abate no valor nutritivo e sensorial da carne caprina de animais mestiços. Ciência e Tecnologia de Alimentos 19:374-379.

Mancini, R. A. and Hunt, M. C. 2005. Current research in meat color Meat Science 71:100-121.

NRC - National Research Council. 2007. Nutrient requirements of small ruminants: Sheep, goats, cervids, and newworld camelids. 6th ed. National Academy Press, Washington, DC.

Pinheiro, R. B.; Jorge, A. M.; Souza, H. B. A. and Boiago, M. M. 2010 Coloração da gordura e qualidade da carne de ovelhas de descarte abatidas em distintos estágios fisiológicos. Arquivo Brasileiro de Medicina Veterinária e Zootecnia 62:468-474.

Rhee, K. S.; Waldron, D. F.; Ziprin, Y. A. and Rhee. K. C. 2000. Fatty acid composition of goat diets $v s$ intramuscular fat. Meat Science 54:313-318

Sanudo, C.; Nute, G. R.; Campo, M. M.; Marõâa, G.; Baker, A.; Sierra, I.; Enser, M. E. and Wood, J. D. 1998. Assessment of commercial lamb meat quality by British and Spanish taste panels. Meat Science 48:91-99

Schoonmaker, J. P.; Fluharty, F. L. and Loerch, S. C. 2004. Effect of source and amount of energy and rate of growth in the growing phase on adipocyte cellularity and lipogenic enzyme activity in the intramuscular and subcutaneous fat depots of Holstein steers. Journal Animal Science 82:137-148.

Smith, S. B. and Crouse, J. D. 1994. Relative contributions of acetate lactate and glucose to lipogenesis in bovine intramuscular and subcutaneous adipose tissue. Journal of Nutrition 114:792-800.

Wood, J. D.; Enser, M.; Fisher, A. V.; Nute, G. R.; Sheard, P. R.; Richardson, R. I.; Hughes, S. I. and Whittington, F. M. 2008. Fat deposition, fatty acid composition and meat quality: A review. Meat Science 78:343-358

Wood, J. D.; Richardson, R. L.; Nute, G. R.; Fisher, A. V.; Campo, M. M.; Kasapidou, E.; Sheard, P. R. and Enser, M. 2003. Effects of fatty acids on meat quality: A review. Meat Science 66:21-32. 